\title{
Past and present dynamics of Skelton Glacier, Transantarctic Mountains
}

\author{
R.S. JONES ${ }^{\mathbf{1}}$, N.R. GOLLEDGE ${ }^{\mathbf{1 , 2}}$, A.N. MACKINTOSH ${ }^{\mathbf{1 , 3}}$ and K.P. NORTON ${ }^{\mathbf{3}}$ \\ ${ }^{1}$ Antarctic Research Centre, Victoria University of Wellington, PO Box 600, Wellington 6140, New Zealand \\ ${ }^{2}$ GNS Science, Avalon, Lower Hutt, New Zealand \\ ${ }^{3}$ School of Geography, Environment and Earth Sciences, Victoria University of Wellington, PO Box 600, Wellington 6140, \\ New Zealand \\ Richard.S.Jones@vuw.ac.nz
}

\begin{abstract}
Any future changes in the volume of Antarctica's ice sheets will depend on the dynamic response of outlet glaciers to shifts in environmental conditions. In the Transantarctic Mountains, this response is probably heavily dependent on the geometry of the system, but few studies have quantified the sensitivity of these glaciers to environmental forcings. Here we investigated the controls, along-flow sensitivity and time-dependent dynamics of Skelton Glacier. Three key outcomes were: i) present-day flow is governed primarily by surface slope, which responds to reduced valley width and large bed undulations, ii) Skelton Glacier is more susceptible to changes in atmospheric temperature than precipitation through its effect on basal sliding near the grounding line, and iii) under conditions representative of Pliocene and Quaternary climates large changes in ice thickness and velocity would have occurred in the lower reaches of the glacier. Based on these new quantitative predictions of the past and present dynamics of Skelton Glacier, we suggest that similar Transantarctic Mountain outlet glaciers could experience greater ice loss in their confined, lower reaches through increased basal sliding and ocean melt under warmer-than-present conditions. These effects are greatest where overdeepenings exist near the grounding line.
\end{abstract}

Received 20 December 2015, accepted 19 April 2016, first published online 24 May 2016

Key words: atmospheric temperature, glacier dynamics, LGM, numerical modelling, Pliocene, precipitation

\section{Introduction}

Understanding the dynamic responses of outlet glaciers has become more urgent following observations of termini retreat (Miles et al. 2013) and dynamic thinning (Pritchard et al. 2009). Antarctic glaciers are simulated to melt (Davies et al. 2014), increase discharge (Winkelmann et al. 2012) and possibly undergo non-linear groundingline retreat (e.g. Favier et al. 2014) with projected atmospheric warming; however, the style and magnitude of such a response is heavily dependent on the glacial system (Oerlemans et al. 1998, Hulbe et al. 2008, Golledge et al. 2014). This is most evident in the Transantarctic Mountains where catchments of different geometries and basal conditions that drain the East Antarctic Ice Sheet (EAIS) can produce contrasting dynamic responses (e.g. Stearns et al. 2008, Golledge \& Levy 2011, Zoet et al. 2012, Golledge et al. 2014). While recent mass balance estimates indicate that these outlet glaciers are in a near steady-state today (e.g. Harig \& Simons 2015), the ice sheet in this region could undergo ice loss and contribute to sea level rise in the coming centuries (e.g. Golledge et al. 2015). Therefore, it is important to better understand the controls on the flow of Transantarctic Mountain outlet glaciers and their sensitivity to changes in environmental conditions.

Here we investigated the dynamic behaviour of Skelton Glacier, under past and present climates. This study had three main objectives, to better understand: i) the extent to which vertical and lateral changes in catchment topography influence the flow of Skelton Glacier, ii) the sensitivity of Skelton Glacier to changes in environmental variables, and iii) how the dynamics of Skelton Glacier varied under contrasting past conditions (Last Glacial Maximum (LGM), Pliocene interglacial, Pliocene glacial).

\section{Previous studies of Skelton Glacier}

Skelton Glacier $\left(159-162^{\circ} \mathrm{E}, 78-79^{\circ} \mathrm{S}\right)$ flows from Taylor Dome at the edge of the EAIS plateau, through the Transantarctic Mountains and feeds into the Ross Ice Shelf (Fig. 1). A catchment of approximately $6000 \mathrm{~km}^{2}$ drains a large névé (an accumulation basin in the midupper reaches of the glacier) to the south-west and steep cirque tributary glaciers on the sides of the Royal Society Range to the north-east (Fig. 2). A line of three nunataks (Névé Nunatak, Halfway Nunatak and Clinker Bluff) 


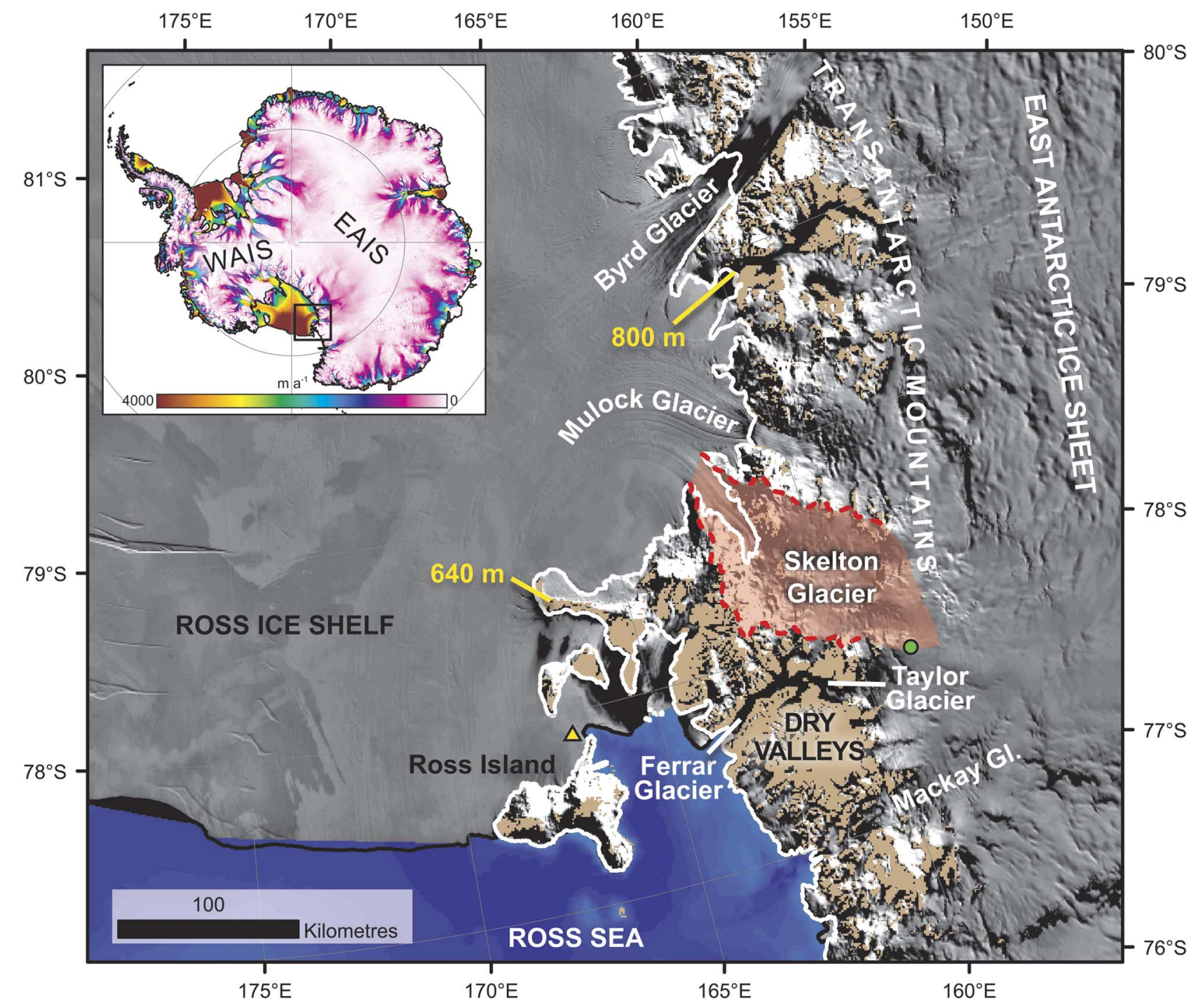

Fig. 1. Geographical context of Skelton Glacier. Inset shows surface velocities of the West Antarctic (WAIS) and East Antarctic (EAIS) ice sheets (Rignot et al. 2011). Skelton Glacier flows from the edge of the EAIS near Taylor Dome (green circle), through the Transantarctic Mountains, to the Ross Ice Shelf. The Last Glacial Maximum ice surface elevation is constrained at DarwinHatherton Glacier ( $\sim 800 \mathrm{~m}$ a.s.1.; Anderson et al. 2004) and at Minna Bluff ( $640 \mathrm{~m}$ a.s.1.; Denton \& Marchant 2000). Ice-free areas (brown), the location of the AND-1B core (yellow triangle; Naish et al. 2009) and the present-day grounding line (white) are also shown.

divide these source areas, which both flow into a laterally confined inlet downstream of Clinker Bluff and the grounding line.

During the International Geophysical Year (1957-59), a series of ice thickness, velocity and meteorological measurements were undertaken as part of a traverse of Skelton Glacier. A seismic survey revealed an almost grounded, floating ice shelf that extends $50 \mathrm{~km}$ from the grounding line, through Skelton Inlet to the Ross Ice Shelf (Crary 1966). At this confluence with the Ross Ice Shelf, the floating portion of Skelton Glacier was measured to be approximately $585 \pm 20 \mathrm{~m}$ thick (Crary 1966). Based on a velocity measurement of $0.28 \mathrm{~m} \mathrm{~d}^{-1}$
( $102 \mathrm{~m} \mathrm{a}^{-1}$; Cameron \& Goldthwait 1961), an annual discharge of $\sim 0.8 \mathrm{~km}^{3}$ was calculated (Wilson \& Crary 1961). At the grounding line, ice surface velocities are recorded as $\sim 115 \mathrm{~m} \mathrm{a}^{-1}$ (Golledge et al. 2014).

The spatial pattern of surface mass balance can be inferred from temperature and precipitation data. Borehole air temperatures measured $10 \mathrm{~m}$ below the surface, which are typically $\pm 1^{\circ} \mathrm{C}$ from the mean annual surface air temperature, changed near-linearly with altitude from $-21^{\circ} \mathrm{C}$ on the shelf $\left(84 \mathrm{~m}\right.$ a.s.1.) to $-42^{\circ} \mathrm{C}$ in the névé (2300 $\mathrm{m}$ a.s.1.) (Crary 1966). Precipitation measurements range from 0.06 to $0.17 \mathrm{~m}$ waterequivalent per year (w.e. $\mathrm{a}^{-1}$ ) at the Ross Ice Shelf 

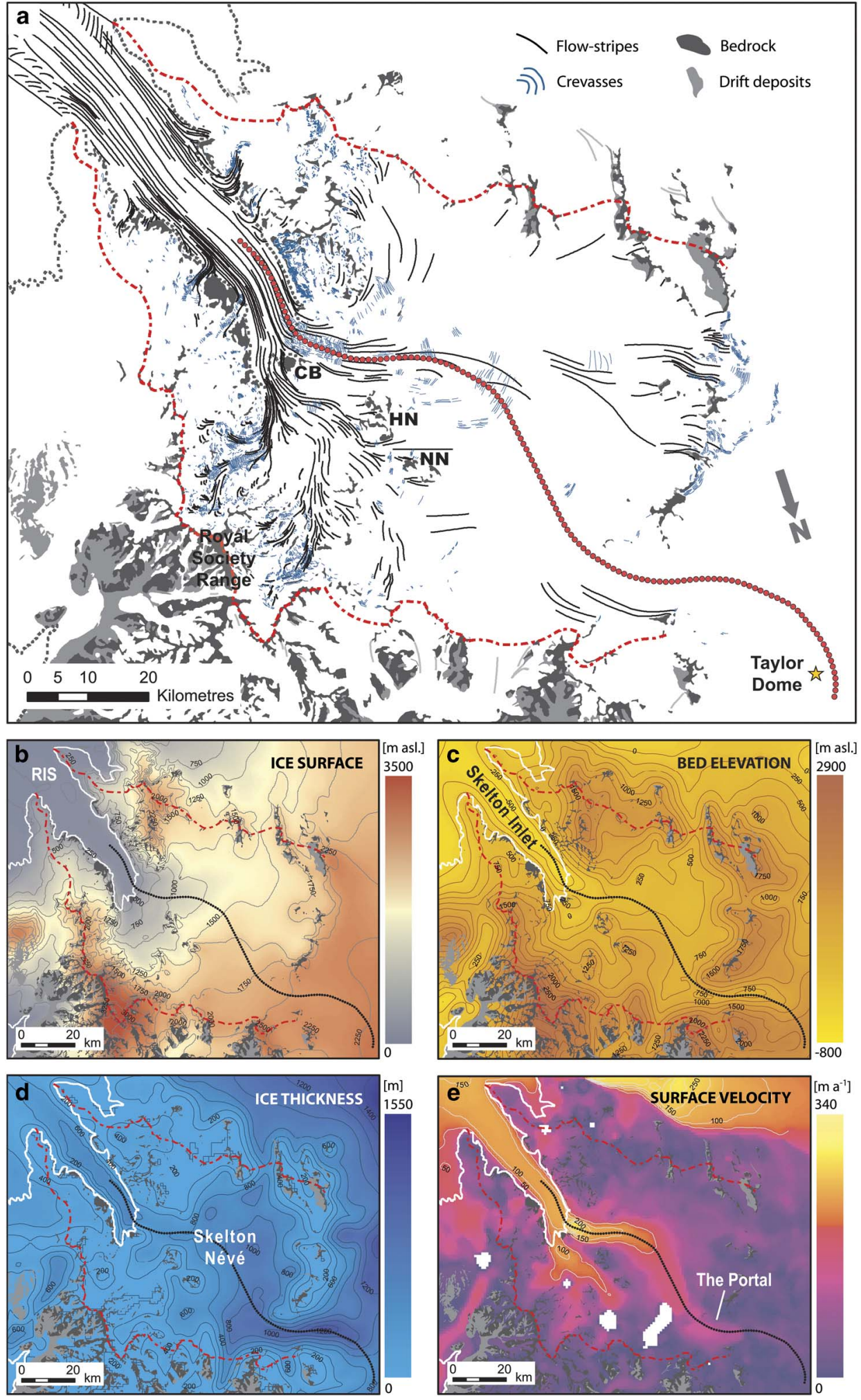

Fig. 2. Features and characteristics of Skelton Glacier from observational datasets. a. Flow stripes and crevasses mapped within the catchment (dashed red line). A glacier flowline (1 km resolution, red circles) extends from Taylor Dome, near to the ice core site (yellow star), to downstream of the present-day grounding line (grey dotted line). A line of three nunataks (Névé Nunatak, NN; Halfway Nunatak, HN; Clinker Bluff, CB) lie adjacent to this main flow path. b.-e. Ice surface elevation, bed elevation and corresponding ice thickness (BEDMAP2; Fretwell et al. 2013), as well as surface velocity magnitude of Skelton Glacier (Rignot et al. 2011). 

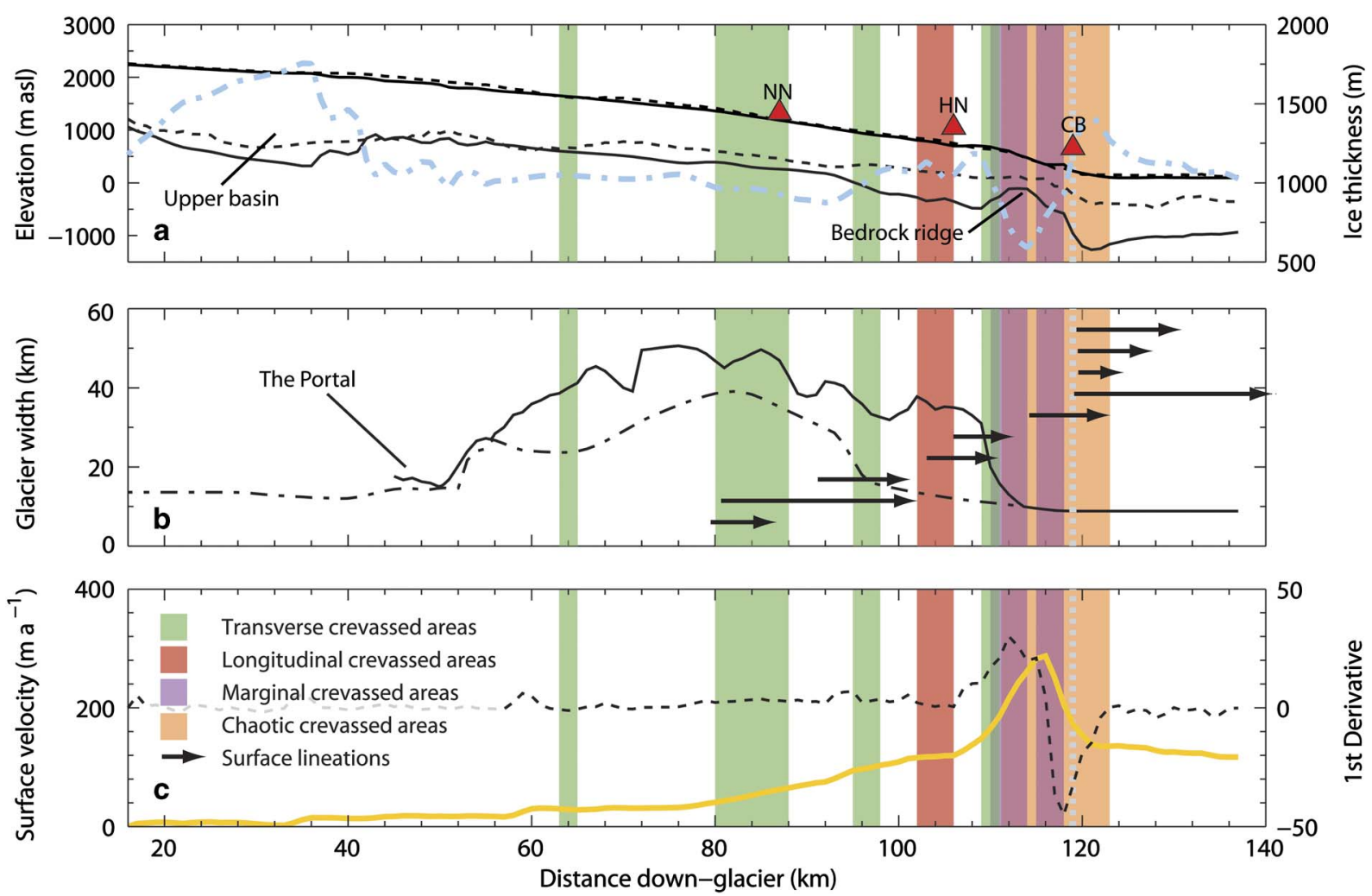

Fig. 3. Flow of Skelton Glacier from observations along the central flowline. a. Surface and bed estimates are from CReSIS (solid black line), with corresponding ice thickness (dot-dashed blue line), and BEDMAP2 (dashed black line). The locations of the adjacent nunataks (Fig. 2) are denoted as triangles. b. Width of glacier along the flowline, to and from the catchment boundaries (solid line) and margins of the flow path (dot-dashed line). c. Ice surface velocity down-glacier (orange line) and its first derivative (dashed black line) (after Rignot et al. 2011). The grounding line is shown as a dashed grey line at $119 \mathrm{~km}$.

confluence, and $0.11 \mathrm{~m}$ w.e. $\mathrm{a}^{-1}(2316 \mathrm{~m}$ a.s.1.) to $0.36-$ $0.4 \mathrm{~m}$ w.e. $\mathrm{a}^{-1}(800-2300 \mathrm{~m}$ a.s.1.) in the névé (Wilson \& Crary 1961, Crary 1966). This suggests that accumulation at Skelton Glacier varies non-linearly with altitude, which is supported by climate reanalysis data that show local precipitation and surface mass balance that are heavily influenced by relief and a prevailing eastto-west precipitation gradient in this area (Lenaerts et al. 2012).

\section{Methods}

Airborne- and satellite-derived datasets allow an ice sheet to glacier scale assessment of surface morphology, bed topography and ice thickness, mass balance and ice surface velocity (e.g. Rignot et al. 2011, Fretwell et al. 2013). Using these datasets, the characteristics of modern glacier flow regimes can be inferred. In particular, flow stripes are known to develop parallel to flow unit boundaries, forming from lateral compression at shear margins and where rapid basal sliding occurs across rough glacier beds (Glasser \& Gudmundsson 2012), while the presence and structure of crevasses, which form perpendicular to the principal strain rate, can inform us about changes in the stress regime (Colgan et al. 2016). Here we mapped the distribution and form of flow stripes and crevasses, using the Landsat Image Mosaic of Antarctica (LIMA) and MODIS Mosaic of Antarctica (MOA), to provide a preliminary assessment of the ice dynamics within the Skelton Glacier catchment.

In order to quantitatively investigate the along-flow dynamics of Skelton Glacier, numerical flowline modelling was carried out. In addition to simulating the glacier under modern conditions, numerical modelling enables the investigation of dynamics for different

Table I. Physical constants and model parameters.

\begin{tabular}{lc}
\hline Parameter & Value \\
\hline Flow enhancement factor* & 2 \\
Sliding rate factor* & $5 \times 10^{-7} \mathrm{~Pa} \mathrm{~m}^{2} \mathrm{a}^{-1}$ \\
Glen's flow law exponent & 3 \\
Sliding exponent & 2 \\
Geothermal heat flux & $56-61 \mathrm{~mW} \mathrm{~m}^{-2}$ \\
Thermal conductivity of ice & $2.4 \mathrm{~W} \mathrm{~m}^{-1} \mathrm{~K}^{-1}$ \\
Universal gas constant & $8.314 \mathrm{~J} \mathrm{~mol}^{-1} \mathrm{~K}^{-1}$ \\
Horizontal domain resolution & $1000 \mathrm{~m}$ \\
\hline
\end{tabular}

*Tuning parameter. 
Table II. Environmental parameters (modern).

\begin{tabular}{lc}
\hline Parameter & Value \\
\hline Precipitation at sea level* $^{*}$ & $1 \mathrm{~m} \mathrm{a}^{-1}$ \\
Precipitation lapse rate* $^{*}$ & $0.02 \mathrm{~m} \mathrm{a}^{-1} \mathrm{~km}^{-1}$ \\
Mean annual temperature at sea level & $-21^{\circ} \mathrm{C}$ \\
Temperature lapse rate & $-9 \mathrm{~K} \mathrm{~km}^{-1}$ \\
Annual temperature range & $25^{\circ} \mathrm{C}$ \\
Ocean temperature (winter) & $-1.8^{\circ} \mathrm{C}$ \\
Ocean temperature (summer)* & $-1.6^{\circ} \mathrm{C}$ \\
Calving rate coefficient* & 1 \\
Relative sea level & $0 \mathrm{~m}$ \\
Degree-day factor & $0.005 \mathrm{~mm} \mathrm{~K}^{-1} \mathrm{~d}^{-1}$ \\
\hline
\end{tabular}

*Tuning parameter, ${ }^{\dagger}$ Crary (1966), ${ }^{*}$ Golledge \& Levy (2011).

boundary condition scenarios (e.g. Jamieson et al. 2012, Winkelmann et al. 2012, Davies et al. 2014). We use a one-dimensional (1-D) finite difference glacier flowline model to predict the likely basal ice temperatures, velocity fields and along-flow extent of basal sliding and internal deformation of Skelton Glacier.

The 1-D flowline model used here has been previously applied to Transantarctic Mountain outlet glaciers (Golledge \& Levy 2011, Golledge et al. 2014). Ice thickness evolves in space and time following the mass conservation equation, and was applied here at a $1 \mathrm{~km}$ horizontal resolution from the ice divide at Taylor Dome to just downstream of the present-day grounding line. Flow of the fully grounded portion of Skelton Glacier was calculated using the shallow ice approximation and a longitudinal averaging scheme (see Golledge \& Levy 2011). This was modified in Skelton Inlet, where ice is only lightly grounded, if at all (Crary 1966). Here, mass loss occurs in the model wherever the bed is below sea level, dependent on the ice thickness relative to the floatation threshold. For ice thickness below this threshold the cell is effectively floating, and mass loss is calculated following an empirically-derived sub-shelf melt relationship with ocean temperature; whereas, for ice thickness above this threshold, ice loss occurs through

Table III. Environmental parameters (past).

\begin{tabular}{lccc}
\hline & \multirow{2}{*}{$\begin{array}{c}\text { Last Glacial } \\
\text { Maximum }\end{array}$} & \multicolumn{2}{c}{ Pliocene } \\
\cline { 3 - 5 } Parameter & Interglacial & Glacial \\
\hline Precipitation at sea level*, $\mathrm{m} \mathrm{a}^{-1}$ & 0.01 & 2 & 1 \\
Precipitation lapse rate, $\mathrm{m} \mathrm{a}^{-1} \mathrm{~km}^{-1}$ & 0.02 & 0.02 & 0.02 \\
Mean annual temperature at sea & -30 & -10 & -25 \\
$\quad$ level ${ }^{*},{ }^{\circ} \mathrm{C}$ & & & \\
Temperature lapse rate, $\mathrm{K} \mathrm{km}^{-1}$ & -9 & -9 & -9 \\
Annual temperature range, ${ }^{\circ} \mathrm{C}$ & 25 & 25 & 25 \\
Ocean temperature (winter), ${ }^{\circ} \mathrm{C}$ & -1.8 & -1.8 & -1.8 \\
Ocean temperature (summer)*, ${ }^{\circ} \mathrm{C}$ & -1.8 & 0.5 & -1.6 \\
Calving rate coefficient* & 0.121 & 1 & 0.6 \\
Relative sea level* ${ }^{*}, \mathrm{~m}$ & 50 & 25 & 40 \\
\hline
\end{tabular}

*Parameter informed by interpretations of ice core or geological data (see text). calving at the grounded terminal cell (Cuffey \& Paterson 2010). A pressure melting adjusted basal ice temperature is calculated based on the thermal conductivity of ice, from the upward geothermal heat flux, sliding-derived strain heating and both vertical and horizontal advections of heat (Cuffey \& Paterson 2010). Centreline surface velocities are calculated in the model from basal sliding, when the basal ice temperature is near to the pressure melting point, and temperature-dependent deformation. The presence and magnitude of subglacial erosion depends on temperature and pressure conditions at the bed, and is calculated using basal shear stress and sliding velocity.

The model was initialized with airborne-derived bed topography and ice thickness data (CReSIS, $\pm 10 \mathrm{~m}$ ), extending $136 \mathrm{~km}$ along the main flow path of Skelton Glacier (Fig. 2). A glacier width was prescribed that varies down-glacier with the margins of the flow path; Skelton Glacier flows through The Portal, widens in Skelton Névé and then narrows upstream of the bedrock ridge in the lower reaches (Fig. 3).

Simulation of the along-flow dynamics of Skelton Glacier firstly requires the present-day profile to be replicated as closely as possible. This was achieved by tuning uncertain flow and environmental parameters while maintaining physical constants (Table I) and measured climate variables (Table II). Empirical data suggest a complex, non-linear precipitation pattern within the catchment, and initial assessment of Skelton Glacier revealed an additional, minor influx of ice from outside the main flow path modelled here. This was accounted for by adjusting both the amount of precipitation at sea level and the precipitation lapse rate.

Under past climatic conditions and ice sheet configurations, steady-state simulations were constrained by regional empirical evidence (Table III). During the LGM, accumulation was minimal $\left(\leq 0.01 \mathrm{~m} \mathrm{a}^{-1}\right)$ and atmospheric temperatures were $\sim 9-10^{\circ} \mathrm{C}$ colder than present at Taylor Dome (Steig et al. 1998). The glacier was probably thicker in its lower reaches as geological data indicates ice surface elevations of 800 and $640 \mathrm{~m}$ a.s.l. south and north of the mouth of Skelton Glacier (Bockheim et al. 1989, Denton \& Marchant 2000, Anderson et al. 2004). For the Pliocene, interglacial conditions are prescribed in the model based on inferences of a globally warmer and wetter climate (e.g. Haywood et al. 2013) and regional sea surface temperatures as high as $3-5^{\circ} \mathrm{C}$ (Winter et al. 2010). Under these conditions, the Skelton Inlet was probably free of grounded ice as geological evidence (AND-1B, Fig. 1) and modelling suggests that the Ross Embayment was largely open water (Naish et al. 2009, Pollard \& DeConto 2009), which is also reflected by a eustatic sea level at that time which was $\sim 25 \mathrm{~m}$ higher than present (Dwyer \& Chandler 2009). Pliocene glacial episodes are poorly constrained; however, thickening in the lower reaches of 

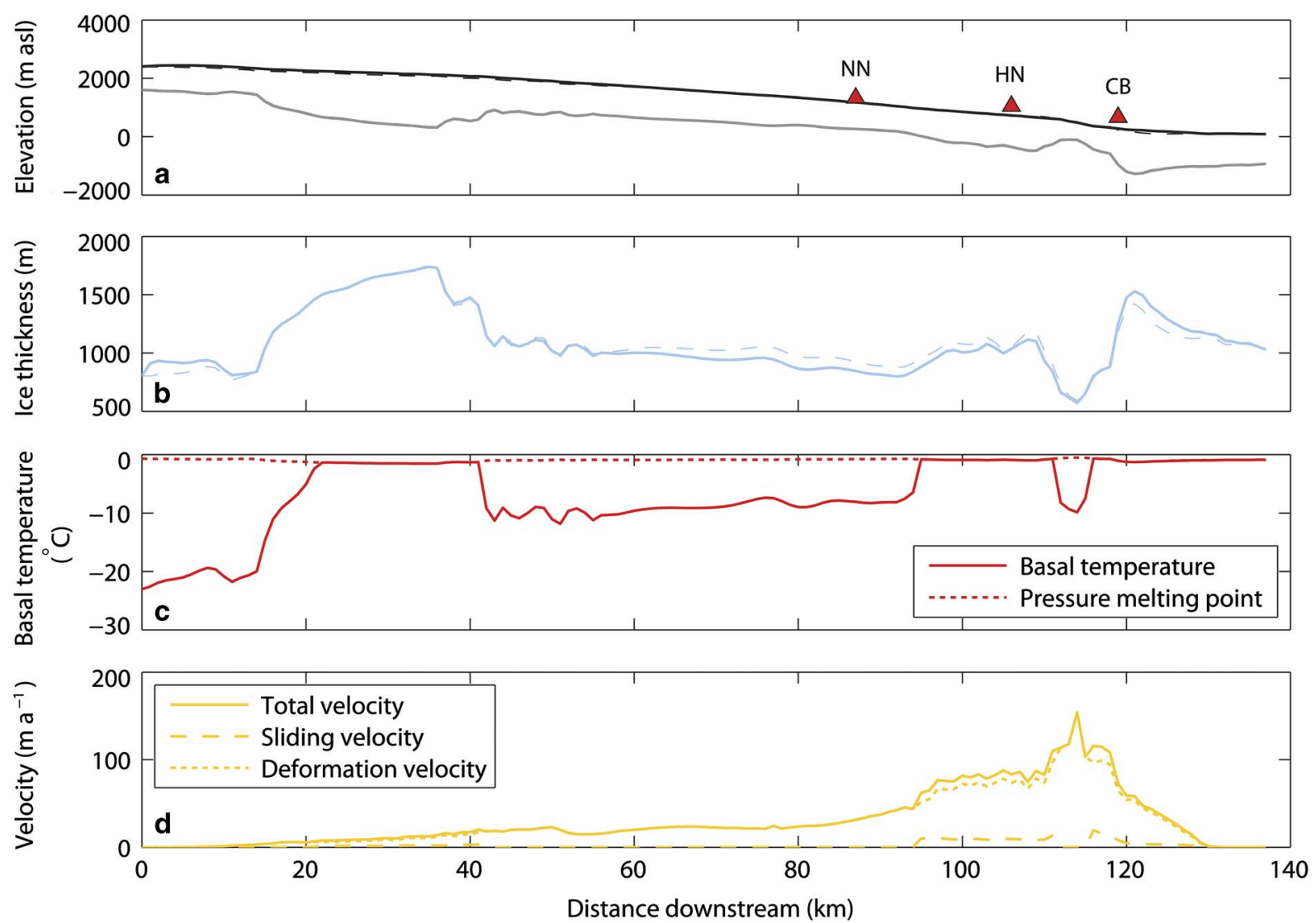

Fig. 4. Simulated present-day Skelton Glacier. a. The modelled ice surface (black, solid) and bed (grey, solid) elevations are consistent with the measured (CReSIS) profiles (dashed), which are manifested as similar along-flow variations in ice thickness (solid and dashed lines, respectively) (b.). d. Flow is predominantly by ice deformation, but sliding is simulated in the overdeepened basins where thick ice enables the basal temperature to reach the pressure melting point (c.). Nunataks are shown as red triangles (labelled as in Fig. 2).

the glacier probably occurred as grounded ice extended past the mouth of Skelton Glacier (Naish et al. 2009, Pollard \& DeConto 2009), and a climate warmer and wetter than the LGM but colder than present can be inferred. The precipitation and temperature lapse rates, as well as the annual temperature range in these simulations are largely unknown, so are kept as modern values, and model flow parameters remain unchanged from the modelled presentday glacier. While using modern values for these environmental parameters is imperfect, the experiments enabled broad differences in the dynamics of Skelton Glacier between the contrasting climates to be identified.

\section{Results}

\section{Dynamic setting as inferred from observational datasets}

Firstly, the modern dynamics of Skelton Glacier that are evident from observational data were assessed. The surface of Skelton Glacier transitions from the elevated ( $2250 \mathrm{~m}$ a.s.1.), low gradient ice sheet plateau, via a steeper Transantarctic Mountains section, to the near-flat floating portion downstream of the grounding line. Integrated and interpolated radar-derived bed data (BEDMAP2) reveal a wide basin in the centre of the catchment that is surrounded by high relief (Fig. 2). The bed slopes gently through the catchment from $\sim 1500$ to $-50 \mathrm{~m}$ a.s.1., but elongate overdeepenings are apparent in topographically confined areas, specifically near The Portal and in Skelton Inlet. At these locations, thickening of the glacier occurs. Ice surface velocities highlight the two main flow paths of Skelton Glacier, the south-west trunk and the north-east arm. Each flow path accelerates in the lower reaches, peaking just upstream of the grounding line (Fig. 2).

Glacier surface flow stripes were mapped to help delimit the catchment boundary and identify flow directions within the catchment. This analysis confirms that ice is sourced from the plateau upstream of Skelton Névé. The main control on the development of flow stripes in the Skelton Glacier catchment is lateral compression, as shown on the surface of tributary glaciers to the north-east and towards the confluence of flow paths near the grounding line. However, basal 
Table IV. Climate parameters used to investigate the sensitivity of Skelton Glacier.

\begin{tabular}{lccc}
\hline & \multicolumn{2}{c}{ Range } & \multirow{2}{*}{$\begin{array}{c}\text { Increments } \\
\text { Parameter }\end{array}$} \\
\cline { 2 - 3 } & Value & $\%$ & 0.05 \\
\hline Precipitation at sea level, $\mathrm{m} \mathrm{a}^{-1}$ & $0.4-1.2$ & $-60-+20$ & 0.05 \\
Precipitation lapse rate, $\mathrm{m} \mathrm{a}^{-1} \mathrm{~km}^{-1}$ & $0.1-0.24$ & $-50-+20$ & 0.01 \\
Mean annual temperature at sea level, ${ }^{\circ} \mathrm{C}$ & $-33--11$ & $-60-+50$ & 1 \\
Ocean temperature (summer), ${ }^{\circ} \mathrm{C}$ & $-1.8--1$ & $-12-+40$ & 0.1 \\
\hline
\end{tabular}

sliding may also occur along the main flow path, as indicated by the initiation of flow stripes in the centre of Skelton Névé (Fig. 2).

The relationships between surface structures and the flow properties of the glacier can be better illustrated in a longitudinal profile along the main trunk (Fig. 3). High resolution CReSIS airborne radar data reveal bed undulations that have a larger amplitude than is evident in BEDMAP2 data. The bed is characterized by an extensive basin in the upper reaches of the glacier (at $\sim 0-40 \mathrm{~km}$ ), where it drains Taylor Dome before flowing through The Portal and into Skelton Névé. Further overdeepenings occur at $\sim 100-110 \mathrm{~km}$ down-glacier and
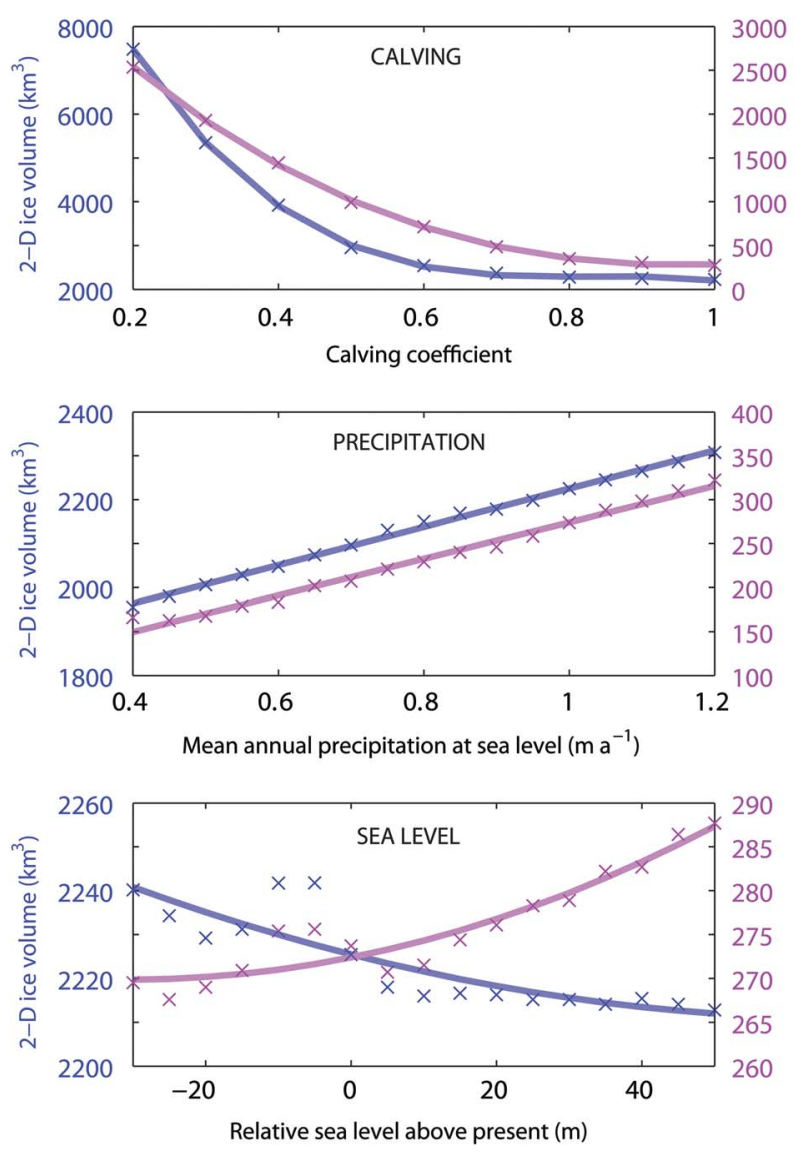

immediately downstream of the grounding line, which are separated by a bedrock ridge. Here, the ice thins from almost $1200 \mathrm{~m}$ to $<600 \mathrm{~m}$ before thickening again to nearly $1500 \mathrm{~m}$. InSAR data reveal a near-exponential increase in surface velocity towards the bedrock ridge and grounding line, which is complemented by similar TerraSAR-X values and in situ GPS measurements (Golledge et al. 2014).

The dynamic response of an outlet glacier to perturbations is sensitive to along-flow variations in both bed topography and valley width (Jamieson et al. 2012). Therefore, we investigated the distribution of along-flow stresses with respect to valley geometry down the flowline. Once ice enters the névé, the steepening ice surface enables a transition in the flow regime. This is apparent as a stepped increase in surface velocity near the top (at $\sim 60 \mathrm{~km}$ ) and then in the centre (at $\sim 80 \mathrm{~km}$ ) of the névé. This regime shift is also evident from the distribution and form of crevasses. In the upper-mid névé, occurrences of transverse crevasses signify areas of extending flow as the ice velocity increases (Fig. 3).
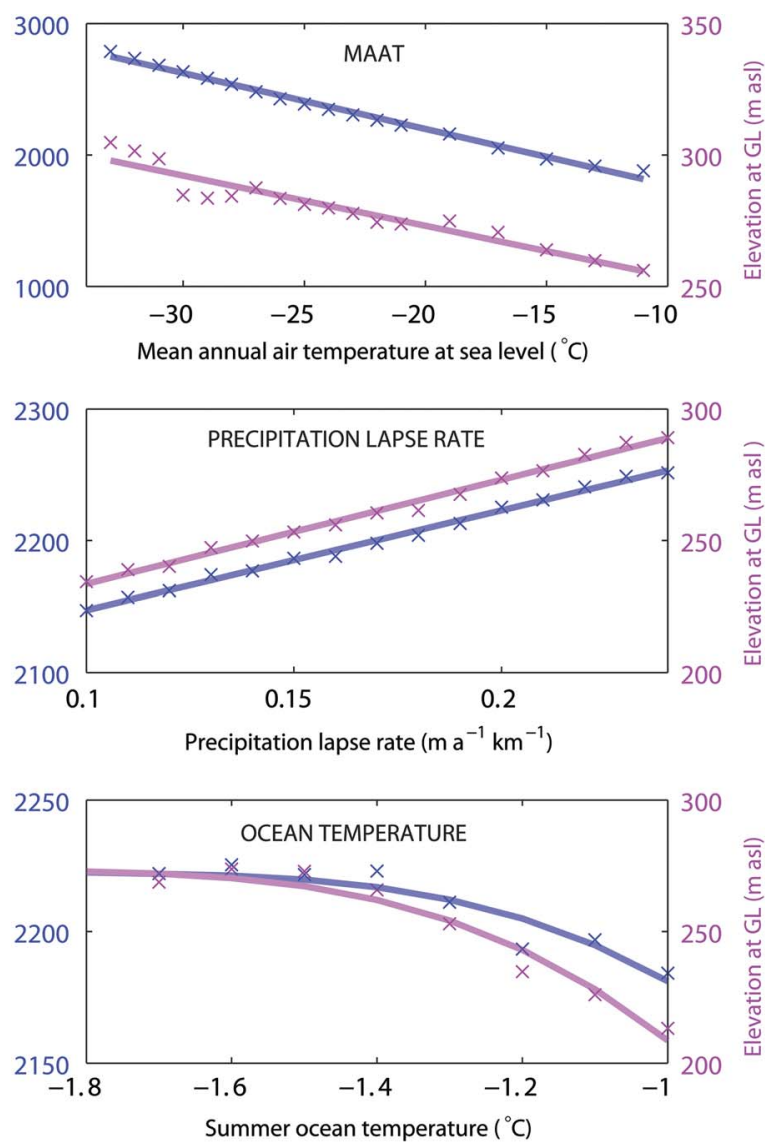

Fig. 5. Sensitivity of Skelton Glacier to environmental variables. Ice volume and elevation at the grounding line (GL) have linear relationships with perturbations in mean annual air temperature (MAAT), amount of precipitation and precipitation lapse rate, but has a greater response for MAAT per percentage change. Calving, sea level and ocean temperature produce non-linear geometric responses, and is exponential for the latter of these. 

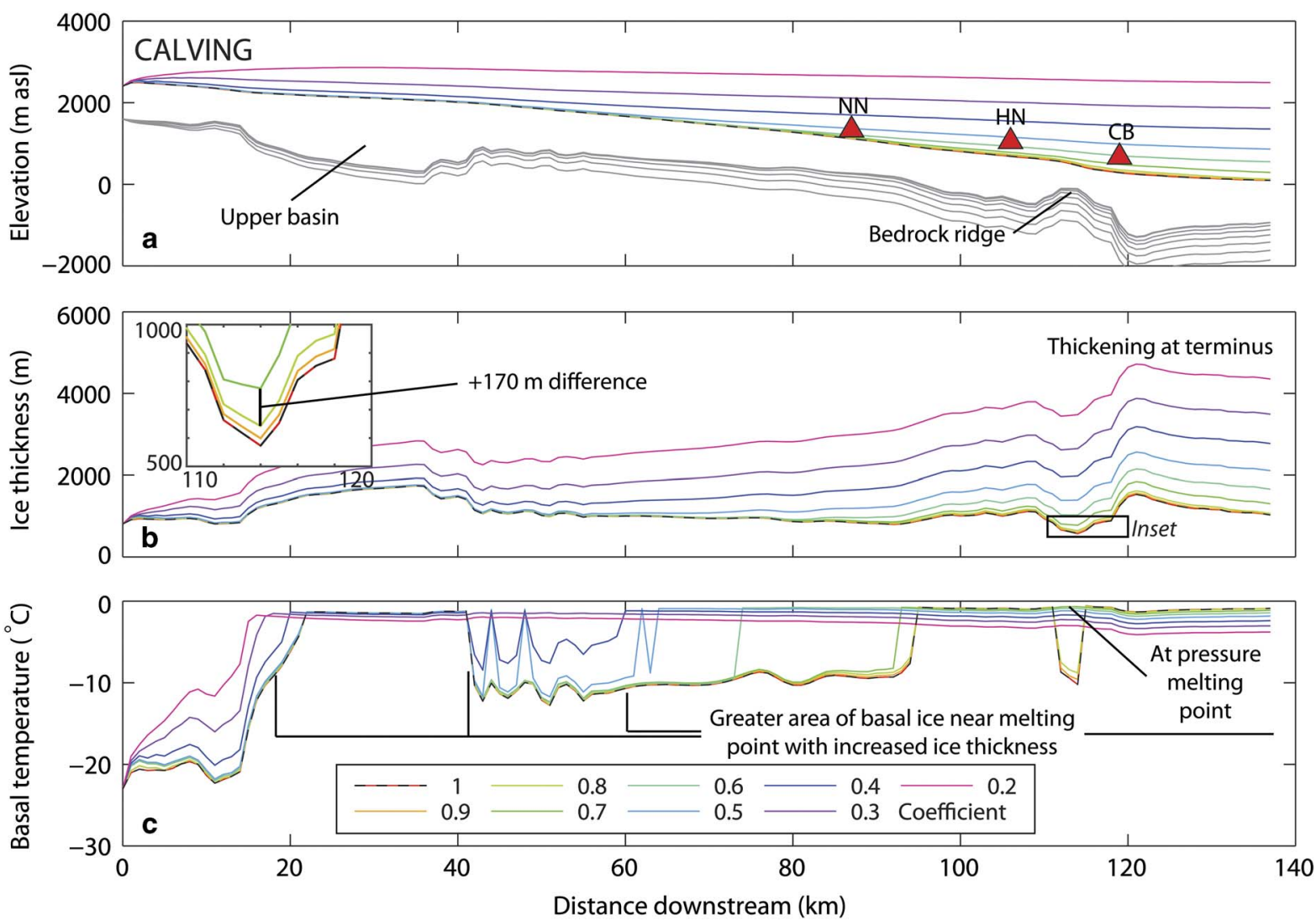

Fig. 6. Simulated along-flow sensitivity of Skelton Glacier to changes in calving. a. Ice surface and bed elevations, where the coloured profiles relate to different calving coefficients applied. Note, the bed elevation (grey) varies with isostatic depression. b. Similar to a buttressing effect, changes in the calving coefficient cause adjustment of ice thickness in the lower reaches. Under thicker ice, the basal ice temperature increases (c.), and at the bedrock ridge, a $\sim 170 \mathrm{~m}$ thickening (b.) enables a predicted switch to basal melt (c.). Present-day profiles are shown by a dashed line, while nunataks are red triangles (labelled as in Fig. 2).

Flow in the lower reaches of Skelton Glacier is probably controlled by reductions in valley width, particularly in the basin between Halfway Nunatak and Clinker Bluff. Surface velocity increases as the flow path narrows and the basin deepens downstream of $\sim 95 \mathrm{~km}$ (Fig. 3). Compressive flow dominates towards the narrowest point of the catchment, evident from marginal crevasses. Ice is then forced to thin and steepen over the bedrock ridge, accelerating to $\sim 270 \mathrm{~m} \mathrm{a}^{-1}$, which is manifested as an icefall where crevassing becomes chaotic. Here, surface geometry adjusts as a consequence of bed topography.

Preliminary assessment of Skelton Glacier from observations suggests several flow characteristics: i) ice flows from Taylor Dome on the Antarctic plateau into Skelton Névé and converges with small tributaries from the north-east, ii) the main trunk flows towards the centre of Skelton Névé and adjacent to the line of nunataks, accelerating in its lower reaches, and iii) extending flow and increased velocity probably occurs as a result of a steepening surface, possibly with a basal sliding component, which then changes to compressive flow as the glacier narrows with a dynamic adjustment of ice flux over the bedrock ridge. Under these interpreted presentday conditions, flow by internal deformation can be inferred along most of Skelton Glacier, with higher driving stress, basal shear and the possibility of basal sliding occurring in the lower reaches of the glacier, upstream of the grounding line.

\section{Simulating the present-day dynamics of Skelton Glacier}

The first objective of this work was to identify controls on the flow of Skelton Glacier. To test and build on the above findings, the present-day dynamics were simulated using a 1-D flowline model.

The tuned Skelton Glacier simulation largely reproduces the observed surface profile and ice geometry (Fig. 4). In particular, the low gradient upper reaches, steepening middle reaches and steep icefall at the bedrock ridge are well replicated. The simulated ice thickness 

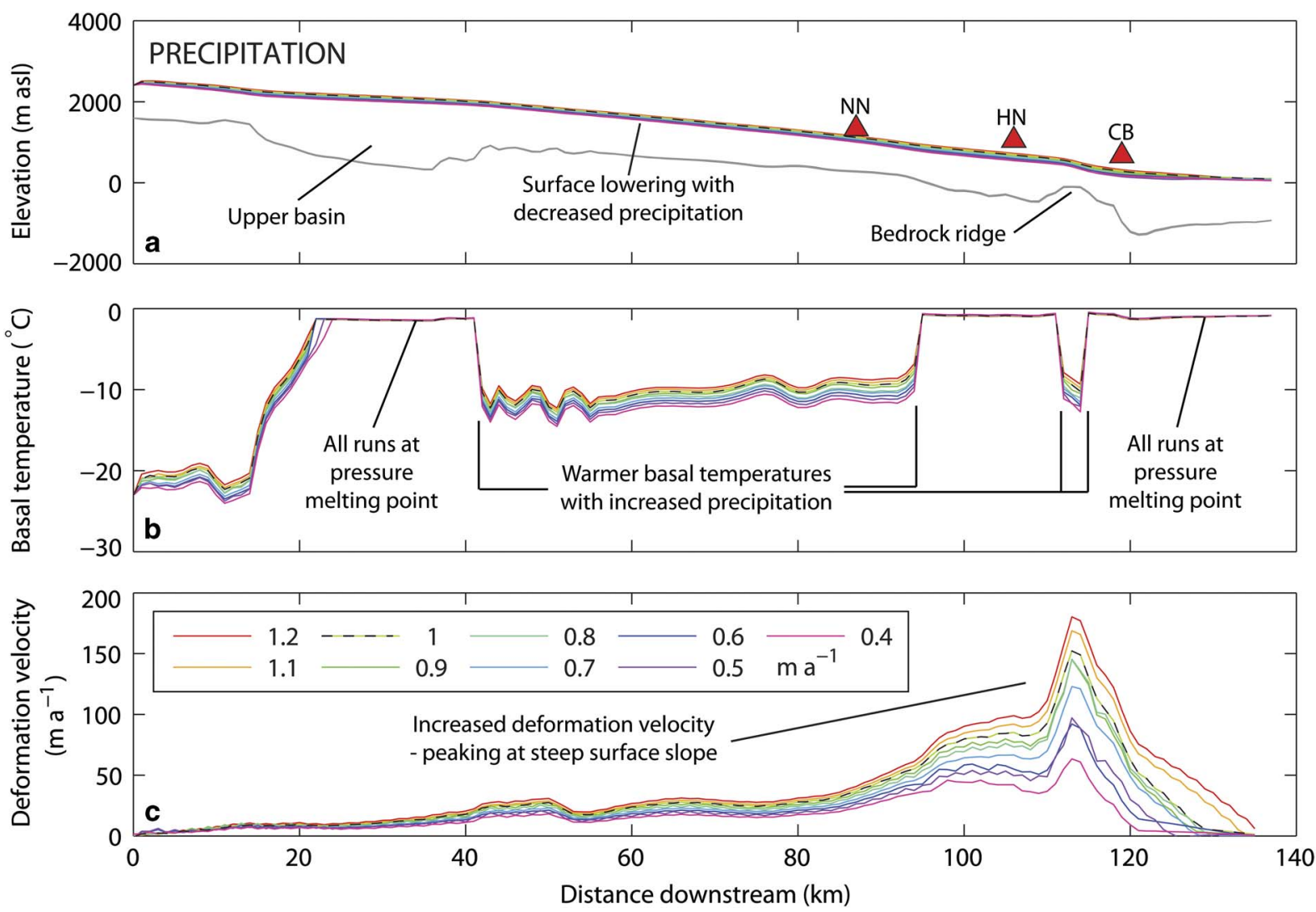

Fig. 7. Simulated along-flow sensitivity of Skelton Glacier to changes in precipitation. a. Ice surface and bed elevations, where the coloured profiles relate to different amounts of precipitation per year. Minor changes are predicted in the surface elevation and extent of basal melt. However, the slight thickening from increased precipitation acts to warm ice at the bed (b.), and internal feedbacks allow large amplitude ice deformation changes in the lower reaches (c.). Present-day profiles are shown by a dashed line, while nunataks are red triangles (labelled as in Fig. 2).

co-varies with measurements down-glacier, diverging by $<100 \mathrm{~m}$. These slight mismatches of ice geometry could not be resolved by exploration of tuning parameters, and instead suggest simplifications in the physics of the model and subtle, unaccounted-for variations in the glacier width. Despite minor disagreement in the magnitude of along-flow profile fluctuations, the simulated Skelton Glacier reproduces observed step-changes in surface velocity downstream; ice velocity accelerates slightly from $60 \mathrm{~km}$, further increases at $80-100 \mathrm{~km}$ and $110 \mathrm{~km}$, and peaks at $116 \mathrm{~km}$ (Fig. 3).

Modelling of Skelton Glacier indicates ice flow by deformation that is greater than sliding along the length of the glacier and enhanced sliding in its lower reaches, which supports our preliminary investigation of Skelton Glacier from observations. Simulated areas of basal sliding correspond to locations of thicker ice in the overdeepened basins, where basal melt is predicted. In its current configuration, the fastest flowing ice occurs in the laterally constrained lower reaches of Skelton Glacier, which peaks where thinner ice and steeper surface slopes are found. Based on these observations, we hypothesize that the lower reaches of the glacier, and possibly also the ice in the overdeepened basins, are most sensitive to environmental perturbations.

\section{Exploring the sensitivity of Skelton Glacier}

The second objective of this study was to investigate the response of Skelton Glacier to changes in environmental variables. The sensitivity of the glacier was tested for climatic perturbations that reflect variance around the simulated present-day values; these include mean annual air temperature (MAAT), precipitation, precipitation lapse rate and summer ocean temperature (with winter ocean temperature kept at $-1.8^{\circ} \mathrm{C}$ ) (Table IV).

Similarly, the effect of relative sea level change was also investigated by simulating Skelton Glacier for a range of sea level values relative to present-day, from $-30 \mathrm{~m}$ a.s.1. to $+50 \mathrm{~m}$ a.s. 1 . in $5 \mathrm{~m}$ increments. The geometry, and therefore dynamics, of Transantarctic Mountain outlet glaciers is significantly influenced in their lower reaches by the presence of grounded ice in the Ross Sea, which provides a buttressing effect that is independent of 

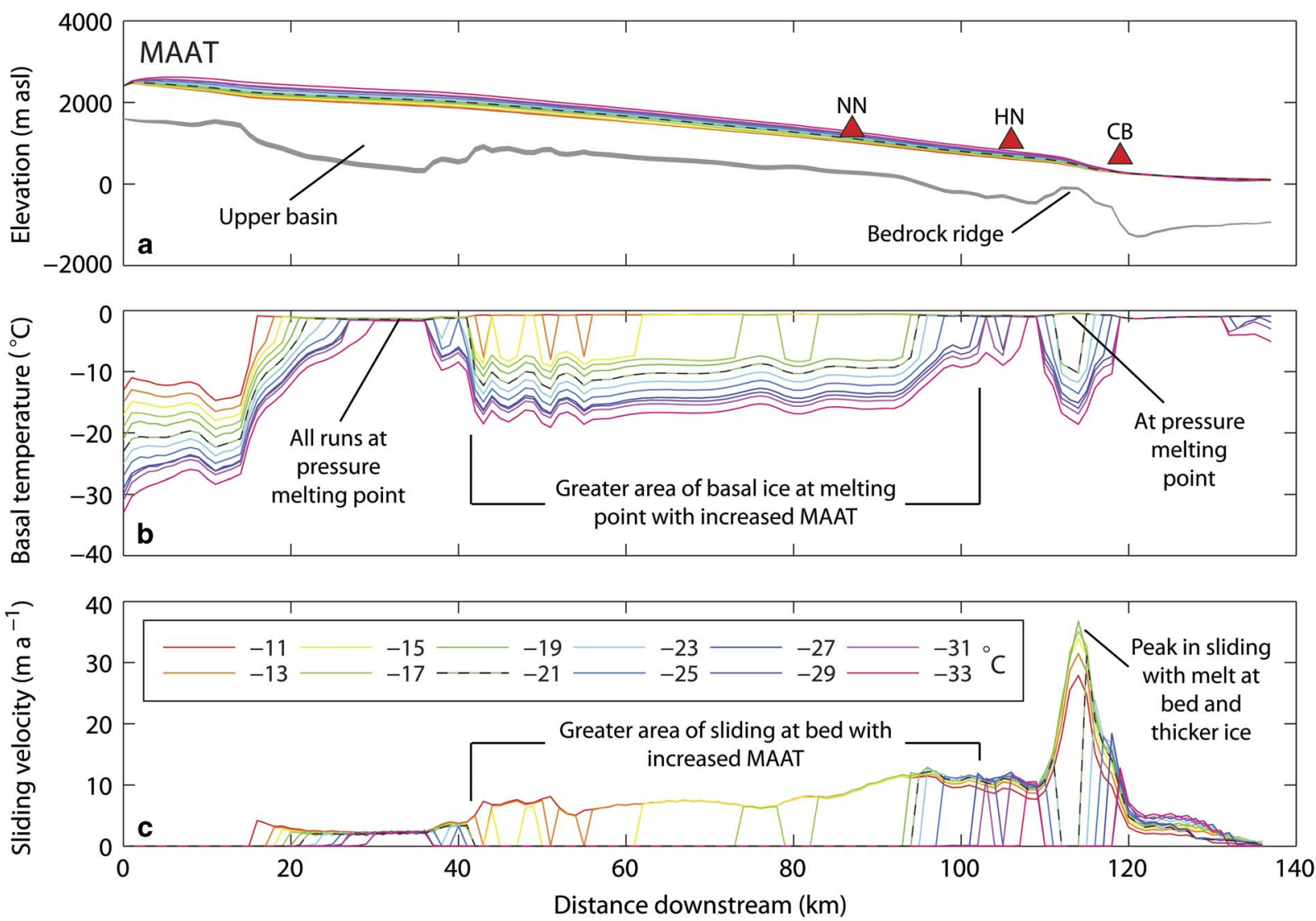

Fig. 8. Simulated along-flow sensitivity of Skelton Glacier to changes in mean annual air temperature (MAAT). a. Ice surface and bed elevations, where the coloured profiles relate to different air temperatures applied. b. Basal ice temperature down the glacier. Despite small surface elevation effects, changes in MAAT are able to alter the area of basal ice reaching melting point, with $-19^{\circ} \mathrm{C}$ causing basal melt to occur at the bedrock ridge. Generally, this melt enables a greater extent and magnitude of basal sliding (c.). Present-day profiles are shown by a dashed line, while nunataks are red triangles (labelled as in Fig. 2).

local environmental variables. However, the extent of Antarctic ice sheets and hence presence or absence of this buttressing effect downstream of Skelton Glacier is dependent on global climate conditions. Therefore, we additionally explore this thickening in the lower reaches of the glacier by changing the calving coefficient (from 0.2 to 1 in 0.1 increments), which acts to limit mass loss at the terminal cell, thereby representing the effect of buttressing.

The largest changes in glacier geometry occur as a result of the externally forced thickening of the lower reaches, achieved here through a reduced calving coefficient (Fig. 5). A small reduction in calving produces a negligible ice volume change and a minor increase in the surface elevation. However, once ice thickens at the grounding line so that the surface elevates above $\sim 500 \mathrm{~m}$ a.s.1. (calving coefficient 0.7 ), both the surface elevation and ice volume increase sharply in response to step decreases in calving. This relationship probably results from effects of the precipitation lapse rate, whereby an increased surface elevation enables greater precipitation to occur, causing the glacier to further thicken and increase volume, which is modulated by mass loss in the lower reaches of the glacier via calving.

Similar non-linear relationships are simulated for changes in ocean temperature and sea level (Fig. 5). For an increase in ocean temperature above present, both the surface elevation at the grounding line and 2-D ice volume change exponentially, although this corresponds to just $\sim 2 \%$ change in ice volume between $-1.6^{\circ} \mathrm{C}$ and $-1^{\circ} \mathrm{C}$. A change in sea level below present-day produces an increase in glacier volume, whereas a sea level above present-day results in a minor decrease in ice volume. The ice surface at the grounding line demonstrates an opposite relationship, whereby the surface elevates from a rise in sea level, possibly as thicker ice can be accommodated in the overdeepened basin near the grounding line despite greater volume loss occurring through calving. However, these changes from sea level perturbations do not significantly affect the glacier geometry, where at most, $\sim 10 \mathrm{~km}^{3}$ volume and $<10 \mathrm{~m}$ elevation change occur per $20 \mathrm{~m}$ sea level change. 

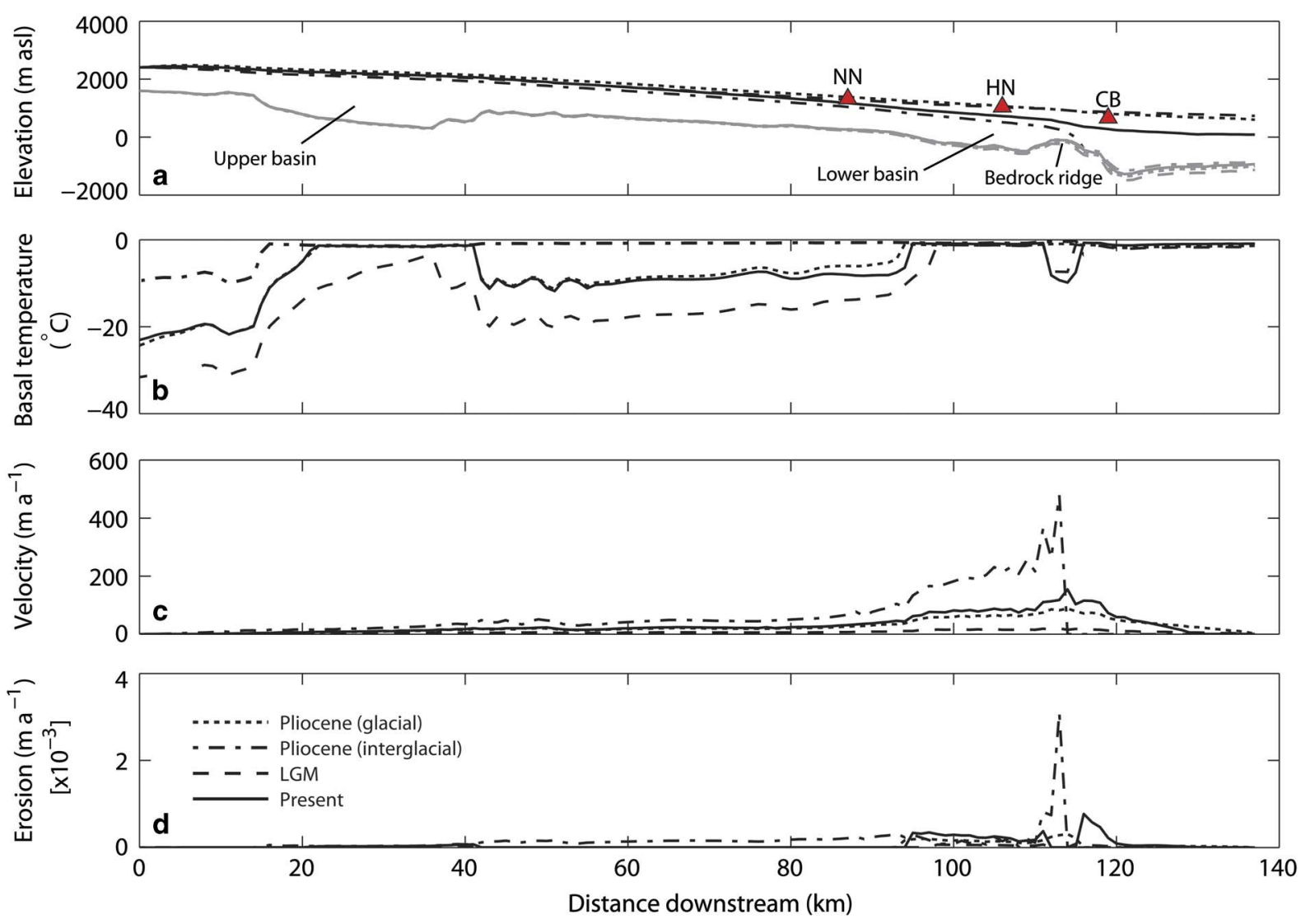

Fig. 9. Simulated configurations and dynamics of Skelton Glacier under present-day, LGM, Pliocene interglacial and Pliocene glacial climates. Shown are the profiles for $\mathbf{a}$. ice surface and bed elevation, b. basal temperature, $\mathbf{c}$. ice velocity and d. basal erosion. The glacier was probably thick enough during glacial (LGM and Pliocene) climates to override the nunataks (red triangles, labelled as in Fig. 2) and was fully grounded, above sea level, during warm interglacial climates, when near-continuous basal sliding and erosion is predicted along the central flowline.

The geometry of Skelton Glacier responds linearly to a step change in MAAT, precipitation and precipitation lapse rate (Fig. 5). An increase in both precipitation and precipitation lapse rate increases the ice volume and the ice surface at the grounding line, whereas a negative relationship exists between MAAT and the glacier geometry (Fig. 5). The magnitude of these effects also differs between the environmental parameters. An 20\% atmospheric (MAAT) warming relative to $0^{\circ} \mathrm{C}$ (from $-21^{\circ} \mathrm{C}$ to $\left.-17^{\circ} \mathrm{C}\right)$ produces $\sim 170 \mathrm{~km}^{3}(\sim 8 \%)$ volume loss. However, an equivalent $20 \%$ change in precipitation and precipitation lapse rate only results in a $\sim 4 \%\left(\sim 80 \mathrm{~km}^{3}\right)$ and $\sim 1 \%\left(25 \mathrm{~km}^{3}\right)$ ice volume change, respectively. While in reality any changes in regional precipitation are likely to be coupled to changes in atmospheric temperature, these sensitivity tests at Skelton Glacier highlight that air temperature is probably the dominating factor influencing glacier geometry.

Ice flowing through the overdeepened basins and in the lower reaches of Skelton Glacier are hypothesized to be most sensitive to environmental perturbations. Therefore, we explored the along-flow dynamic sensitivity to changes in calving, precipitation and atmospheric temperature. Incrementally reducing the calving coefficient results in a progressively thicker glacier in its lower reaches with diminished thickening upstream, replicating the effect of buttressing at the terminus. Today, basal temperatures reach the pressure melting point in the upper basin and in the smaller overdeepenings either side of the bedrock ridge. Under a buttressed Skelton Glacier scenario (Fig. 6), thickening extends the area of the bed that is at pressure melting point, suggesting that basal melt could occur in the portion upstream of Névé Nunatak. The glacier is forced to thin over the bedrock ridge that currently prohibits basal melt, however, melt can be enabled here with sufficient thickening; an increase of ice thickness by $\sim 170 \mathrm{~m}$ (calving coefficient of 0.8 to 0.7 ) exceeds this threshold, causing the basal ice temperature to reach pressure melting point.

While changes in both precipitation and atmospheric temperature produced linear ice geometry responses, the dissimilar magnitudes of ice volume change suggest differing dynamic effects along the length of Skelton Glacier. An increase in precipitation causes a slight 
thickening along the profile, with an opposite effect under reduced precipitation (Fig. 7). While the area of basal ice that reaches melting point is unaffected by these changes, the minor thickening from increased accumulation acts to increase basal temperature, dominating over possible cooling effects from enhanced precipitation. This slight warming of the glacier acts to soften the ice and in turn, together with strain heating, is able to facilitate greater deformation velocities in the steeper lower reaches of the glacier.

A contrasting dynamic response is simulated for changes in air temperature, despite similar lowmagnitude ice thickness adjustments. Warmer air temperatures substantially increase the extent of basal melt along the profile, increasing sliding velocity and causing the glacier to thin dynamically, which leads to a negative mass balance (Fig. 8). In particular, a $2^{\circ} \mathrm{C}$ increase in MAAT from $-21^{\circ} \mathrm{C}$ (present) to $-19^{\circ} \mathrm{C}$ enables basal melt at the bedrock ridge. The $2^{\circ} \mathrm{C}$ rise above present at the bedrock ridge allows the glacier to transition from zero sliding here to peak sliding along the profile that can be explained by a positive feedback; as ice deformation increases from warmer surface temperatures, strain heating on slopes is able to increase, and then sliding increases once basal melt is possible, which encourages strain heating in non-sliding areas upstream. Sliding at the bed thins the glacier along its length and this reduced ice thickness then hinders the sliding potential, which is shown at the bedrock ridge for warmer glacier scenarios that result from air temperatures $>-19^{\circ} \mathrm{C}$. The occurrence of melt along more of the bed allows for both more extensive and higher magnitude sliding velocity at the bed. Sliding would probably extend continuously from $\sim 25 \mathrm{~km}$ upstream of Névé Nunatak to the terminus under a $6^{\circ} \mathrm{C}$ warmer air temperature, and from the head of the upper basin under $8-10^{\circ} \mathrm{C}$ warmer temperatures.

In summary, the volume and surface elevation of Skelton Glacier can respond linearly or exponentially, depending on which environmental variable is changed. In particular, buttressing at the terminus from expanded ice in the Ross Sea (represented as a reduced calving coefficient) allows significant thickening of the lower reaches and therefore a greater glacier volume. Thickening has the potential to increase the area of basal melt along the glacier; however, the basal conditions are also dependent on the environmental conditions at the surface. For example, changes in precipitation can affect the temperature of the ice that then influences the amount of ice deformation, although this process causes only moderate volume change. Variations in MAAT lead to greater adjustments in ice volume than from precipitation, primarily from its ability to modify the extent of basal melt and therefore sliding at the bed. These sensitivity tests also identify that areas of the bed can quite easily transition between contrasting dynamic states if near an ice thickness threshold, for example, at the bedrock ridge.

\section{Simulating Skelton Glacier under different climates}

The third objective of this work was to investigate the dynamics and basal conditions of Skelton Glacier under past climates. Sensitivity experiments illustrate that the glacier responds differently along its length depending on the environmental conditions. Here, we investigated variations in the dynamics for contrasting LGM (colder and drier), Pliocene interglacial (warmer and wetter) and Pliocene glacial (colder and wetter) climatic episodes.

Data-constrained simulations of Skelton Glacier reveal striking changes in the glacial regime for different ice geometries and environmental conditions (Fig. 9). The modelled glacier geometry at the LGM reproduces a low gradient surface elevation profile, with thickening in the lower reaches of Skelton Glacier sufficient to cover the nunataks adjacent to the flow path. This thickening causes slightly warmer-than-present basal ice at the bedrock ridge, but elsewhere basal temperatures are simulated to be cooler and basal melt in the lower basin (at $\sim 100 \mathrm{~km}$ ) is less extensive than today. Together, the shallow surface slope and small extent of basal melt produce very low velocities, with minor erosion at the bed limited to the overdeepenings either side of the bedrock ridge. During a simulated Pliocene interglacial regime, warm ocean temperatures force the glacier to terminate at the bedrock ridge above sea level, with a lower than present surface elevation near the terminus. Despite this reduced ice thickness, warm atmospheric temperatures allow basal melt to occur from the upper basin to the terminus, with near-continuous basal erosion predicted along the length of the glacier. A steep ice surface in the lower reaches greatly enhances the velocity, which peaks $\left(>400 \mathrm{~m} \mathrm{a}^{-1}\right)$ together with basal erosion $\left(\sim 0.003 \mathrm{~m} \mathrm{a}^{-1}\right)$ at the terminus. A buttressed Skelton Glacier during Pliocene glacial episodes probably had a surface profile similar to that at the LGM; however, the relatively warmer and wetter climate at this time instead results in velocities and basal conditions similar to today. One key difference between present-day and Pliocene glacial regimes occurs at the bedrock ridge, where the thicker ice of the Pliocene configuration facilitates basal melt that, in turn, enables modest erosion at the bed $\left(\sim 0.0005 \mathrm{~m} \mathrm{a}^{-1}\right)$.

\section{Discussion}

\section{Topographically controlled flow of Skelton Glacier}

Evaluation of the Skelton Glacier system from satellite and aerial observations as well as flowline modelling provides an improved understanding of the controls on 
the flow of Transantarctic Mountain outlet glaciers. Skelton Glacier thickens upstream of large bed undulations, for example at the bedrock ridge above the grounding line, which causes the ice surface to steepen down-glacier in a similar manner to neighbouring Ferrar Glacier (Golledge \& Levy 2011). Surface velocity peaks where the surface is steepest; however, the velocity increases further upstream where the glacier narrows. Longitudinal extending flow is coincident with this accelerating surface velocity but not with the presence of basal melt, and therefore, indicates that flow is controlled primarily by changes in surface slope and glacier width; mass conservation dictates that the ice flux dynamically adjusts to a varying geometry. These results are similar to the along-flow interpretations at Taylor and Ferrar glaciers (Kavanaugh \& Cuffey 2009, Golledge \& Levy 2011) that ice velocity peaks as it cascades over bed obstacles and is propagated in areas of thicker ice, which is contrary to the idea of bed topography restricting glacier flow (Johnson \& Staiger 2007). However, at Skelton Glacier, width is also recognized as an important control on ice flux in the absence of major variations of bed topography. Together, these interpretations have implications for numerous Transantarctic Mountain outlet glaciers, which typically have overdeepened basins in their upper reaches and near their modern grounding lines, and become more laterally constrained in their downstream reaches (Fretwell et al. 2013).

\section{Sensitivity of Skelton Glacier to environmental forcings}

Sensitivity experiments revealed that the geometry of Skelton Glacier responds linearly or exponentially depending on the environmental forcing. Enhanced oceanic forcing, from a raised relative sea level or ocean temperature, would cause mass loss. This effect is simulated to be small for a sea level change above present, and small but exponential for an increase in ocean temperature above present, indicating a floatationlimiting factor for the modern configuration of Skelton Glacier. Sea level rise results in retreat and mass loss as long as ice thickness is below the floatation threshold. However, in the overdeepened basin near the grounding line where ice is sufficiently thick, loss through floatation is limited whereas increases in ocean temperature can act unimpeded to exponentially increase sub-ice melt (Golledge \& Levy 2011).

Buttressing of Skelton Glacier by either a thicker Ross Ice Shelf or grounded ice in the Ross Sea is demonstrated to probably cause the most significant increases in ice volume. The effect of thickening in the lower reaches acts to increase the ice surface elevation, leading to greater precipitation from a positive lapse rate and potential further thickening. Therefore, the degree of enhanced lateral drag (or 'buttressing') governs upstream thickening and the potential for further thickening from positive feedback. While the transition from grounded to floating ice or the interaction between Skelton Glacier and buttressing ice is not fully incorporated in these modelling experiments, it can be assumed that with sufficient thickening that exceeds floatation thickness in its lower reaches the grounding line would advance (Schoof 2007).

Changes in precipitation and MAAT lead to linear responses of Skelton Glacier, manifested as adjustments of ice volume and surface elevation at the grounding line. These relationships are expected for Antarctic glaciers as a decrease in temperature or an increase in precipitation enlarges and elevates the accumulation area. Any changes in surface mass balance that result in increased ice volume, act to thicken ice at the grounding line with the potential for glacier advance (Schoof 2007). However, the higher elevation of the glacier surface resulting from increased precipitation can alternatively lead to surface steepening and enhancement of the driving stress and ice flux (Winkelmann et al. 2012). At Skelton Glacier, a positive change in air temperature resulted in a greater modelled ice volume loss than from an equivalent negative change in precipitation. This is superficially similar to the modelled response of temperate glaciers to climate change, where warming-induced mass loss occurs because of the sensitivity of the melt process to increasing temperature (e.g. Oerlemans et al. 1998, Davies et al. 2014). However, in this case the more southerly location $\left(\sim 78^{\circ} \mathrm{S}\right)$, and therefore significantly colder temperatures $\left(-21^{\circ} \mathrm{C}\right.$ MAAT) at Skelton Glacier, demonstrates that an alternative, ice-dynamic mechanism is required to explain the modelled sensitivity to air temperature.

Outlet glaciers respond dynamically along their length following perturbations in environmental forcings or stresses near the grounding line. Bed topography is shown to provide a critical control on the along-flow response at Skelton Glacier, principally through its effect on ice thickness and therefore potential basal melt. In particular, threshold responses can result from bed variations in certain locations, for example at the bedrock ridge. Here, a $2^{\circ} \mathrm{C}$ increase in atmospheric temperature enables a gradual transition to basal melt in that area, which then allows a stretch of continuous sliding that peaks just upstream of the grounding line. The steep ice surface at the bedrock ridge also facilitates an internal feedback in response to a change in precipitation. Rather than any discernible effect on melt and sliding at the bed, an increase in precipitation instead significantly amplifies ice deformation in this area of the glacier. Such disparities in the dynamic response upstream of the grounding line reveals why the ice volume of Skelton Glacier adjusts at different magnitudes for equivalent environmental perturbations, and highlights the important role of basal melt in potentially influencing ice flow. 
The extent of basal melt, and therefore the potential for enhanced sliding and ice flux, is greater per step change in atmospheric forcing for thicker and higher velocity outlet glaciers, such as Beardmore Glacier (Golledge et al. 2014). Nevertheless, the importance of this basal sliding mechanism for causing significant mass loss is dependent on the stability of the grounding line, which is primarily influenced by bed topography (Schoof 2007) and buttressing (Dupont \& Alley 2005). The main flow path of Skelton Glacier is currently grounded upstream of a large overdeepening and is therefore not considered vulnerable to retreat; however, the combination of basal sliding and floatation-driven grounding-line retreat may lead to mass loss for the northern arm of Skelton Glacier that currently occupies a deep basin (Golledge et al. 2014). Furthermore, as ice thickness near the grounding line of Skelton Glacier is heavily influenced by buttressing at the terminus, thinning or retreat of the Ross Ice Shelf could then lead to enhanced ice flux across the grounding line through climate-driven basal sliding in the lower reaches of the glacier until a new steady-state profile is reached.

\section{Glacier dynamics and basal conditions under past climates}

Exploring Skelton Glacier under different climatic conditions provides insight into its potential steady-state dynamics and configurations. Modelling of Skelton Glacier predicts, for contrasting past climates, minimal differences in its upper reaches but large topographically controlled variations in the configuration and behaviour downstream. This is in agreement with other studies that suggest that the upper reaches of these glaciers remain stable (e.g. Sugden et al. 1993), whereas the lower reaches undergo dynamic variations in ice geometry (e.g. Naish et al. 2009, Golledge \& Levy 2011).

A terrestrial, fully grounded Skelton Glacier during Pliocene interglacial periods would have probably had sufficient basal melt to slide at its bed along most of its length. As with temperate glaciers today (e.g. Oerlemans et al. 1998), greatest velocities occurred near its terminus where the ice surface steepens sharply. The surface profile was probably very different during colder and buttressed episodes, when a very low gradient surface existed. However, despite similar simulated glacier geometries during Pliocene glacial periods and the LGM, slight differences in environmental conditions produced distinguishable basal conditions and dynamics. Skelton Glacier probably behaved much like today during Pliocene glacial periods, with basal melt occurring in the deeper basins and along-flow acceleration manifested in the confined, lower reaches of the glacier peaking at the bedrock ridge. As a result of lower atmospheric temperatures during the LGM, basal melt probably only occurred in the lower basin, near Halfway Nunatak, and together with the low surface gradient, minimal ice velocities could be reached (Golledge \& Levy 2011). Only under Pliocene conditions, when a significantly warmer climate existed and ice was sufficiently thicker than today during glacial episodes, was basal melt possible at the bedrock ridge.

Basal erosion is very much dependent on whether melt occurs at the bed and the magnitude of basal sliding. Therefore, minor erosion is predicted in the upper and lower basins where ice is thick in all climate scenarios, but no erosion is simulated between $\sim 42 \mathrm{~km}$ and $\sim 95 \mathrm{~km}$ during either Pliocene glacial periods, the LGM or at present. As high basal temperatures and velocities are modelled during Pliocene interglacial periods, erosion is possible over the bedrock ridge, and peaks where driving stresses and basal shear stresses are high. Nevertheless, the lower surface elevation at this time would prevent erosion of the higher elevation nunataks, while marginal areas of the glacier away from the central incised trough would probably experience reduced basal melt and erosion of the bed from thinner ice (Golledge et al. 2013). In mountainous terrain where outlet glaciers are topographically controlled, the foci of erosion most probably remains fixed over time; however, the magnitude of erosion varies depending on the ice flux at those points, and thus the large basins at Skelton Glacier have probably existed throughout the Late Cenozoic and will probably continue to deepen.

\section{Conclusions}

As yet, few studies have investigated the sensitivity of Transantarctic Mountain outlet glaciers to environmental forcings, and the necessity of such studies is made more apparent considering the varied dynamic responses anticipated between glacial systems. Here, aerial- and satellite-derived data were used to provide preliminary interpretations of the present-day flow regime of Skelton Glacier, and 1-D flowline modelling then allowed a quantitative prediction of along-flow dynamics under modern and hypothetical conditions. The modern flow of Skelton Glacier is governed primarily by surface slope, which responds to reduced valley width and large bed undulations, much like other Transantarctic Mountain glaciers. However, sensitivity experiments carried out in this study reveal the importance of basal sliding for maintaining ice flux. Specifically, Skelton Glacier is shown to be most susceptible to perturbations in atmospheric temperature, outside potential buttressing effects.

Under past climates, high magnitude changes in ice thickness and velocity occurred in the lower reaches of the glacier. This was primarily the result of the presence or absence of buttressing at the terminus as well as 
contrasting atmospheric temperatures, with both effects influenced heavily by the topography. It is likely that basal sliding and at least minor erosion occurred in the two overdeepened basins in the lower reaches of the glacier, either side of the bedrock ridge, under all glacial and interglacial climates during the Pliocene and Quaternary. However, warm-based sliding along nearly the entire bed was only possible during peak Pliocene warming.

Under future atmospheric and oceanic warming, these findings indicate that outlet glaciers similar to Skelton Glacier will probably undergo greater ice loss. In particular, enhanced ice flux from increased basal sliding is expected to occur in locations where overdeepened basins exist in the lower reaches of a glacier.

\section{Acknowledgements}

We acknowledge financial support for the project from the Antarctic Science Bursary. R.S.J. was supported by a VUW Victoria Doctoral Scholarship and New Zealand Antarctic Research Institute grant. N.R.G. and A.N.M. were supported by the New Zealand Government (MBIE) Past Antarctic Climate and Future Implications programme. We thank D. Braaten for airborne radar data (CReSIS), R.M. McKay, B.C. Storey and S.S.R. Jamieson for critical discussions, and two anonymous reviewers who helped to improve the structure of the manuscript.

\section{Author contributions}

R.S.J., N.R.G., A.N.M. and K.P.N. designed the research. N.R.G. developed the flowline model, and R.S.J. evaluated the modern observational datasets and carried out the glacier modelling. R.S.J. drafted the manuscript and all authors contributed to the final paper.

\section{References}

Anderson, B.M., Hindmarsh, R.C.A. \& Lawson, W.J. 2004. A modelling study of the response of Hatherton Glacier to Ross Ice Sheet grounding line retreat. Global and Planetary Change, 42, 143-153.

Bockheim, J.G., Wilson, S.C., Denton, G.H., Andersen, B.G. \& Stuiver, M. 1989. Late Quaternary ice-surface fluctuations of Hatherton Glacier, Transantarctic Mountains. Quaternary Research, 31, 229-254.

Cameron, R.L. \& Goldthwait, R.P. 1961. The US-IGY contribution to Antarctic glaciology. International Association of Scientific Hydrology, 55, 7-13.

Colgan, W., Rajaram, H., Abdalati, W., McCutchan, C., Mottram, R., Moussavi, M.S. \& GrigsBY, S. 2016. Glacier crevasses: observations, models and mass balance implications. Reviews of Geophysics, 54, 10.1002/2015RG000504.

Crary, A.P. 1966. Mechanism for fiord formation indicated by studies of an ice-covered inlet. Geological Society of America Bulletin, 77, 911-930.
Cuffey, K.M. \& Paterson, W.S.B. 2010. The physics of glaciers, 4th ed. Burlington, MA: Elsevier, 704 pp.

Davies, B.J., Golledge, N.R., Glasser, N.F., Carrivick, J.L., Ligtenberg, S.R.M., Barrand, N.E., van den Broeke, M.R., Hambrey, M.J. \& Smellie, J.L. 2014. Modelled glacier response to centennial temperature and precipitation trends on the Antarctic Peninsula. Nature Climate Change, 4, 993-998.

Denton, G.H. \& Marchant, D.R. 2000. The geologic basis for a reconstruction of a grounded ice sheet in McMurdo Sound, Antarctica, at the Last Glacial Maximum. Geografiska Annaler Physical Geography, A82, 167-211.

Dupont, T.K. \& Alley, R.B. 2005. Assessment of the importance of ice-shelf buttressing to ice-sheet flow. Geophysical Research Letters, 32, 10.1029/2004GL022024.

Dwyer, G.S. \& Chandler, M.A. 2009. Mid-Pliocene sea level and continental ice volume based on coupled benthic $\mathrm{Mg} / \mathrm{Ca}$ palaeotemperatures and oxygen isotopes. Philosophical Transactions of the Royal Society - Mathematical, Physical and Engineering Sciences, A367, 157-168.

Favier, L., Durand, G., Cornford, S.L., Gudmundsson, G.H., Gagliardini, O., Gillet-Chaulet, F., Zwinger, T., Payne, A.J. \& Le BrocQ, A.M. 2014. Retreat of Pine Island Glacier controlled by marine ice-sheet instability. Nature Climate Change, 4, 117-121.

Fretwell, P., Pritchard, H.D., Vaughan, D.G. \& 52 others. 2013. BEDMAP2: improved ice bed, surface and thickness datasets for Antarctica. Cryosphere, 7, 375-393.

Glasser, N.F. \& Gudmundsson, G.H. 2012. Longitudinal surface structures (flowstripes) on Antarctic glaciers. Cryosphere, 6, 383-391.

Golledge, N.R. \& Levy, R.H. 2011. Geometry and dynamics of an East Antarctic Ice Sheet outlet glacier, under past and present climates. Journal of Geophysical Research - Earth Surface, 116, 10.1029/2011JF002028.

Golledge, N.R., Marsh, O.J., Rack, W., Braaten, D. \& Jones, R.S. 2014. Basal conditions of two Transantarctic Mountains outlet glaciers from observation-constrained diagnostic modelling. Journal of Glaciology, 60, 855-866.

Golledge, N.R., Kowalewski, D.E., Naish, T.R., Levy, R.H., Fogwill, C.J. \& GASSON, E.G.W. 2015. The multi-millennial Antarctic commitment to future sea-level rise. Nature, 526, 421-425.

Golledge, N.R., Levy, R.H., McKay, R.M., Fogwill, C.J., White, D.A., Graham, A.G.C., Smith, J.A., Hillenbrand, C.D., Licht, K.J., Denton, G.H., Ackert, R.P., MaAs, S.M. \& Hall, B.L. 2013. Glaciology and geological signature of the Last Glacial Maximum Antarctic ice sheet. Quaternary Science Reviews, 78, 225-247.

Harig, C. \& Simons, F.J. 2015. Accelerated West Antarctic ice mass loss continues to outpace East Antarctic gains. Earth and Planetary Science Letters, 415, 134-141.

Haywood, A.M., Hill, D.J., Dolan, A.M., et al. 2013. Large-scale features of Pliocene climate: results from the Pliocene Model Intercomparison Project. Climate of the Past, 9, 191-209.

Hulbe, C.L., Scambos, T.A., Youngberg, T. \& Lamb, A.K. 2008. Patterns of glacier response to disintegration of the Larsen B ice shelf, Antarctic Peninsula. Global and Planetary Change, 63, 1-8.

Jamieson, S.S.R., Vieli, A., Livingstone, S.J., Cofaigh, C.Ó., Stokes, C., HillenBrand, C.D. \& Dowdeswell, J.A. 2012. Ice-stream stability on a reverse bed slope. Nature Geoscience, 5, 799-802.

Johnson, J.V. \& Staiger, J.W. 2007. Modeling long-term stability of the Ferrar Glacier, East Antarctica: implications for interpreting cosmogenic nuclide inheritance. Journal of Geophysical Research Earth Surface, 112, 10.1029/2006JF000599.

Kavanaugh, J.L. \& CufFEY, K.M. 2009. Dynamics and mass balance of Taylor Glacier, Antarctica: 2. Force balance and longitudinal coupling. Journal of Geophysical Research - Earth Surface, 114, 10.1029/2009JF001329. 
Lenaerts, J.T.M., van den Broeke, M.R., van de Berg, W.J., van Meijgaard, E. \& Munneke, P.K. 2012. A new, high-resolution surface mass balance map of Antarctica (1979-2010) based on regional atmospheric climate modeling. Geophysical Research Letters, 39, 10.1029/2011GL050713.

Miles, B.W.J., Stokes, C.R., Vieli, A. \& Cox, N.J. 2013. Rapid, climate-driven changes in outlet glaciers on the Pacific coast of East Antarctica. Nature, 500, 563-566.

Naish, T., Powell, R., Levy, R. \& 53 others. 2009. Obliquity-paced Pliocene West Antarctic ice sheet oscillations. Nature, 458, 322-328.

Oerlemans, J., Anderson, B., Hubbard, A., Huybrechts, P., Johannesson, T., Knap, W.H., Schmeits, M., Stroeven, A.P., van de Wal, R.S.W., Wallinga, J. \& Zuo, Z. 1998. Modelling the response of glaciers to climate warming. Climate Dynamics, 14, 267-274.

Pollard, D. \& DeConto, R.M. 2009. Modelling West Antarctic ice sheet growth and collapse through the past five million years. Nature, 458, 329-332.

Pritchard, H.D., Arthern, R.J., Vaughan, D.G. \& Edwards, L.A. 2009. Extensive dynamic thinning on the margins of the Greenland and Antarctic ice sheets. Nature, 461, 971-975.

Rignot, E., Mouginot, J. \& Scheuchl, B. 2011. Ice flow of the Antarctic ice sheet. Science, 333, 1427-1430.
Schoof, C. 2007. Ice sheet grounding line dynamics: steady states, stability, and hysteresis. Journal of Geophysical Research - Earth Surface, 112, 10.1029/2006JF000664.

Stearns, L.A., Smith, B.E. \& Hamilton, G.S. 2008. Increased flow speed on a large East Antarctic outlet glacier caused by subglacial floods. Nature Geoscience, 1, 827-831.

Steig, E.J., Brook, E.J., White, J.W.C., Sucher, C.M., Bender, M.L., Lehman, S.J., Morse, D.L., Waddington, E.D. \& Clow, G.D. 1998. Synchronous climate changes in Antarctica and the North Atlantic. Science, 282, 92-95.

Sugden, D.E., Marchant, D.R. \& Denton, G.H. 1993. The case for a stable East Antarctic Ice Sheet: the background. Geografiska Annaler Physical Geography, A75, 151-154.

Wilson, C.R. \& CRARY, A.P. 1961. Ice movement studies on the Skelton Glacier. Journal of Glaciology, 3, 873-878.

Winkelmann, R., Levermann, A., Martin, M.A. \& Frieler, K. 2012. Increased future ice discharge from Antarctica owing to higher snowfall. Nature, 492, 239-242.

Winter, D., SJunneskog, C. \& Harwood, D. 2010. Early to mid-Pliocene environmentally constrained diatom assemblages from the AND-1B drillcore, McMurdo Sound, Antarctica. Stratigraphy, 7, 207-227.

Zoet, L.K., Anandakrishnan, S., Alley, R.B., Nyblade, A.A. \& WiEns, D.A. 2012. Motion of an Antarctic glacier by repeated tidally modulated earthquakes. Nature Geoscience, 5, 623-626. 